\title{
Research on Taxation Issues in Public Hospitals in China
} Bo SU ${ }^{1,2, \star}$, Dan $\mathrm{CHEN}^{1,2}$ and Xiao-jun $\mathrm{WU}^{3}$

${ }^{1}$ School of Management, Hubei University of Chinese Medicine, Wuhan, Hubei, China

\author{
${ }^{2}$ Key Projects Sciences Research Base of Humanities and Social in Hubei Province \\ The Development Research Center of Traditional Chinese Medicine \\ Wuhan, Hubei, China
}

${ }^{3}$ Wuhan Donghu Scenic Area Taxation Chinese Medicine, Wuhan, Hubei, China

${ }^{*}$ Corresponding author

Keywords: Public Hospitals; Taxes; Tax Information Disclosure.

\begin{abstract}
The purpose of the study is to reveal the taxation policies and problems faced by public hospitals and provide advice and support for the improvement of taxation in public hospitals. Descriptive analysis method was used to analyse the changes in the taxation system of public hospitals and the current taxation policies. The results show that the connotation of some taxation systems is not definite; the taxation awareness of public hospitals is weak, the interpretation of taxation policies is low, and the implementation of tax incentives is insufficient; the level of tax collection is not high, and the supervision is not reliable. Finally, some suggestions are put forward based on the conclusion: improve the level of tax legislation, formulate and improve tax laws and regulations; learn from foreign experience, handle the tax collection of public hospitals after the "competition reform", and improve the financial information and tax information disclosure system.
\end{abstract}

\section{Introduction}

Public hospitals are the main body of China's medical service system, and its public welfare plays a significant role in improving the quality of the population and maintaining social stability. The national health and well-being have become the political responsibility of the people of all countries. The improvement of public health is one of the leading indicators for examining the comprehensive competitiveness of a country. The public welfare of public hospitals requires the government's financial resources to be maintained. The state needs to use taxation and other financial means to raise funds to provide medical social security.

\section{Changes in the Taxation System of Public Hospitals Since the Founding of New China}

Institutional change refers to the dynamic process of the new system to generate, replace or change the old system [1]. Institutional changes have "top-down" legal provisions promulgated and are government-ordered, and there are also "bottom-up" inductive changes that interest groups have in order to safeguard their interests. The institutional change in China is mainly based on the "topdown" institutional changes, which is due to China's government management system.

There is a trajectory of the taxation system of public hospitals in China. The changes in the taxation system of public hospitals in China have mainly gone through three stages. The first stage was the establishment of New China until the late 1980s and early 1990s. At this stage, the state made several partial adjustments to the taxation system of various industries. The medical-related taxation system was reflected in hospitals, outpatient departments, counties and townships level health. Almost all medical institutions in the hospital gave preferential tax treatment, aiming to exert the social welfare of the medical industry and exercise social responsibility on behalf of the state. Medical institutions did not need industrial and commercial registration and naturally did not have to pay the regular industrial and commercial tax that was generally paid by enterprises at that time. The second stage was from the 1990s to the beginning of the 21 st century. China's market economy with socialist characteristics was opened, and the tax system was reformed accordingly. 
The unified industrial and commercial tax was abolished, and business tax and value-added tax were levied on different industries. In 2000, medical institutions were classified as for-profit and non-profit, and public hospitals were classified as non-profit medical institutions with preferential policies for exemption from business tax. The third stage is from the beginning of the 21 st century to the present. The tax policy of public hospitals has always followed the national preferential policies for non-profit organisations to exempt business tax. The exemption is conditional and must provide medical service income within the price stipulated by the price department.

\section{Tax Classification of Public Hospitals}

The taxes involved in public hospitals mainly include: value-added tax and surcharges, personal income tax, corporate income tax, property tax, vehicle and vessel use tax, and stamp duty.

Value-added tax: from May 1st, 2016, the hospital was officially included in the life service category as the VAT taxpayer after the "reform of the camp". The other operating income of public hospitals is approved as taxable income. Other operating income mainly includes income from horizontal research funds, income from rental non-medical purposes, parking fee income, training fee income and magazine advertising fee income. The treatment will be the focus of reforms in the implementation of the "reform of the camp" in public hospitals [2].

Individual income tax: mainly for the withholding of all taxable income obtained by individual employees, including wages and salaries, labour remuneration, etc. Hospital financial personnel need to be reminded that the subsidy allowance, which is paid from remuneration and committee budget to each employee in the form of welfare and securities, is also taxable. The employee yearend award can be calculated as a monthly salary. In a tax year, the one-off bonus tax benefit is only allowed once [3].

Corporate income tax: the corporate income tax that a public hospital needs to pay mainly includes income from rental housing, income from further training, income from parking fees, income from interest, and income from the canteen. Medical service income and financial subsidy income are exempt from income tax, and the operating income directly used to improve medical service conditions is a deductible taxable income.

Public hospitals also need to pay stamp duty, property tax, vehicle and vessel use tax, and land value-added tax according to the specific tax-related conditions. Imported instruments and equipment supplies are not subject to import tariffs for science, education and medical activities.

\section{Current Tax Problems in Public Hospitals}

Some of the connotations in the tax system are not clear. There is no special provision for hospitals in corporate income tax. The tax incentives currently applicable to hospitals are mainly the tax benefits of non-profit organisations. The fiscal and taxation ([2009] No. 122) stipulates that the five types of income of non-profit hospitals are tax-free. Also, their income from commercial activities to improve medical and health conditions are eligible for income tax deductions, and they are exempt from property taxes, vehicle and vessel taxes, and urban land use taxes. It can be seen that the state still recognises public hospitals for certain business activities and encourages earning income to optimise hospital medical conditions. Document No. 122 refines the scope of tax exemption but has not elaborated comprehensive approaches as to how to define the scope of tax exemption for "improving medical and health conditions", how to review, and how to confirm the amount of deduction.

Public hospitals have insufficient taxation awareness. Public hospitals have long enjoyed tax incentives, as well as relieves from local governments. Therefore, from the hospital management to the financial department, tax work is generally not taken seriously. Also, the level of knowledge of financial personnel is uneven; there is as well a lack of useful cost management mode and cost control mechanism. The outcome is that the tax and fee factors cannot be considered together when assessing cost and expenses. Hospital leaders are fortunate in tax audits, and problems such as unpaid, underpaid, and delayed tax payment are not handled following the regulations. Often in the 
tax audit, through the pulling of some relationships or paying the penalty to cross the customs, tax evasion is becoming more and more serious [4].

The ability of hospital financial personnel to interpret taxation policy is not high. Financial personnel are unfamiliar with the tax law and cannot understand provision and payment of specific taxes clearly, resulting in the state tax incentives not being implemented well. For example, income from hospital disability, widowed persons and martyrs can be reduced by a certain amount of income tax according to the relevant regulations of the local people's government, provided that they hand in application to the relevant department. Another example is the year-end bonus, according to the National Taxation ([2005] No. 9) document, you can enjoy a tax benefit calculation method based on monthly salary once every year; another example is that for salaries, there is a deductible amount within the commercial health insurance from the self-paid part of " 5 insurances and 1 fund". If the hospital finance staff does not learn and understand these regulations in time, many right tax incentives cannot be timely conveyed and implemented, and some employees therefore unknowingly pay extra taxes.

The ability of tax collection is weak, and so is the supervision. The hospital enjoys preferential tax policies, the overall tax amount is low, and the details of tax reduction and exemption are complicated, which causes the tax department to pay no attention. As the tax officials are not familiar with the corresponding policies, the scope of the collection policy is unclear, and it is impossible to convey tax information to the hospital timely. It is difficult to tell whether the hospitals have missed reports or have underpaid cannot be found and feedback in time. Some nonpublic hospitals have taken some improper means to obtain public tax-exempt qualifications, and tax officials cannot distinguish and apply punishments in time. The seriousness of taxation has been questioned.

\section{Public Hospital Taxation Recommendations}

China is going through a phase of taxation reform, the expansion of the reform of the business, the expectation of corporate income tax adjustment and the extension of the personal income tax deductible project and the increase in the deductible amount, reducing the tax burden of enterprises and individuals has become a trend. The current efforts to reform the drawbacks of the tax system and improve the tax quality of public hospitals give play to the public welfare of public hospitals and better serve the general public.

The government should strengthen the enforcement of tax legislation, as well as formulate and improve tax laws and regulations. Taxation is the secondary distribution of social wealth and a means of reflecting social equity. In the past, the role of the tax law was too much emphasis on the economic adjustment function, and more focus on the formulation of tax incentives, but lacking provisions on the allocation of tax incentives. It is more common to manage taxes in the form of administrative documents. The tax laws governed by administrative means lead to the proliferation of administrative power and rent-seeking. Some private hospital operators see the tax law's particular focus on non-profit hospitals, and they obtain the qualifications of non-profit hospitals in order to defraud the state's support and financial subsidies, resulting in its bad social impact. The state should establish a sound and transparent tax law system and build a multi-sector linkage mechanism for the exercise of tax functions. Relevant departments should communicate with hospitals to ensure comprehensive and timely tax collection.

Drawing on foreign experience, we will deal with the "reform of the camp and increase the number of subsidies". After the reform of the camp, the medical service will be taxed. There is a theory that the public welfare products should be exempted from the VAT and improve the overall welfare level of the society. China has previously exempted public hospitals from business tax, and now it is to be exempt from the VAT, reflecting the state's legal support for public welfare. Under the EU legal framework, all medical services are exempted from VAT according to different supply subjects and tax exemption basis, and public hospitals are directly excluded from the taxable scope [5]. Public hospitals in the UK are further subdivided into charities and are recognised as charities for tax exemption. There are also countries that have implemented comprehensive taxation on 
public hospitals. They believe that general taxation can demonstrate fairness, avoid taxation distorting resource allocation, and help reduce the cost of hospital tax planning. For example, Australia, New Zealand and other countries implement full-scale taxation. The New Zealand GST system is recognised as the complete VAT system. The national conditions and social conditions are different. The hospitals and other life service industries are also different. Based on the experience of foreign countries, combined with China's political foundation and economic foundation, we should establish a tax collection and management system suitable for public hospitals in China.

There needs to be a financial information and tax information disclosure system. In the information age, an open and transparent financial system is essential for the sustainable development of public hospitals. Especially nowadays, medical institutions, as a focus of social conflicts, require particular transparency in finance and taxation [6]. On August 3, the State Council issued "Guiding Opinions of the General Office of the State Council on Reforming and Improving the Comprehensive Supervision System for the Medical and Health Industry" document ([2018] No. 63), which has clearly demonstrated that it is necessary to establish and improve a sound public hospital comprehensive budget management, cost management, financial reports, information honesty and internal and third-party audit mechanisms, in order to increase supervision of public hospital personnel expenditures, capital construction and equipment purchase expenditures, liabilities, foreign investment, and fund balances [7]. Publicizing financial tax information and returning the right to know to taxpayers and medical practitioners are conducive to stimulating public trust and understanding of public hospitals, which can strengthen the social responsibility of public hospitals and the establishment of taxpayer awareness.

\section{Summary}

Public hospital taxation is part of the state's fiscal allocation, involving the state's institutional arrangements and economic arrangements, and the reform of tax-related systems has a process of continuous improvement. The research and discussion of related issues have a specific role in promoting the reform of the medical system of public hospitals in China.

\section{Acknowledgement}

The research was funded by the Hubei Provincial Education Department Education Science Planning Leading Group (Topic Number: 15GB063) and the General Foundation of Key Projects Sciences Research Base of Humanities and Social in Hubei Province the Development Research Center of Traditional Chinese Medicine (Number of General Foundation: ZX2015Y07.

\section{References}

[1] Wu Jingjing, Zhang Yunan, et al. Analysis of the status quo of institutional changes in public hospital tax reform under the background of "camp reform" [J]. Finance and Accounting News, 2018 (13): 48-51. (in Chinese)

[2] Zheng Daxi. The taxation legal policy applicable to public hospitals and the accounting treatment of taxes and fees payable [J]. China Health Economics, 2018, 34 (1): 82-84. (in Chinese)

[3] Xiao Xingyan. Discussion on Taxation Issues in Public Hospitals [J]. Finance and Accounting, 2018 (6): 111-112. (in Chinese)

[4] Guo Yunbo. Talking about the Finance and Taxation Management of Public Hospitals [J]. Contemporary Accounting, 2015 (05): 59-60. (in Chinese)

[5] Organization for Economic Cooperation and Development (OECD), the EU Common VAT System Act (EU CVSD), Article 132, paragraph 1 (b) (c) (d) (e). 
[6] Li Yuping. Research on Finance and Taxation Issues in Public Hospitals in China [J]. Value Engineering, 2013 (25): 158-159. (in Chinese)

[7] General Office of the State Council, "Guiding Opinions of the General Office of the State Council on Reforming and Perfecting the Comprehensive Supervision System for the Medical and Health Industry”. No. 63 [2018], Article 11, 2018-8-3. (in Chinese) 